\title{
LITERATURE REVIEW HUBUNGAN ASUHAN KEPERAWATAN PELAYANAN BPJS DAN PELAYANAN UMUM TERHADAP KEPUASAN PASIEN
}

\author{
Bayu Imanuddin ${ }^{1)}$, Dwi Indah Normaningrum ${ }^{2)}$, Takismen ${ }^{3)}$ \\ ${ }^{1}$ Dosen STIKes Yatsi Tangerang, ${ }^{2}$ Program Studi S1 Keperawatan STIKes Yatsi Tangerang, \\ ${ }^{3}$ Universitas Raharja \\ 1'bayuiman23@gmail.com, ${ }^{2}$ dwiindah3293@gmail.com, ${ }^{3}$ takismen@raharja.info
}

\begin{abstract}
Abstrak
Kepuasan adalah hal yang digunakan dalam panutan sebagai penentu kesuksesan suatu program pelayanan yang melibatkan harapan pasien kepada petugas untuk memberikan pelayanan yang baik dan adil tidak membeda-bedakan antar pasien baik pengguna bpjs kesehatan maupun umum harus diperlakukan sama. Tujuan penelitian ini adalah untuk mengetahui gambaran umum mengenai hubungan asuhan keperawatan pelayanan bpjs dan pelayanan umum terhadap kepuasan pasien. Metode literature review yang digunakan dalam pengumpulan jurnal menggunakan google scholar dan mendeley terbitan tahun 2015-2020. Hasil literature review di atas adanya hubungan asuhan keperawatan pelayanan bpjs dan pelayanan umum terhadap kepuasan pasien. Hal ini berdasarkan hasil kepuasan pasien dimana kepuasan pasien pengguna bpjs lebih rendah dari pasien umum. Hal ini terbukti dari setiap jurnal yang ada menunjukkan kepuasan pasien bpjs yang masih rendah. Dan terdapat perbedaan antara pasien bpjs dan pasien umum terhadap kualitas yang diberikan dalam pelayanan seperti perlakuan yang dibedabedakan, proses pendaftaran yang berbelit-belit, dan merasa tidak dilayani sesuai standar prosedur.
\end{abstract}

Kata kunci : kepuasan pasien, pasien bpjs, pasien umum.

\begin{abstract}
Satisfaction is something that is used in role models as a determinant of the success of a service program that involves the patient's expectations of officers to provide good and fair services and does not discriminate between patients, both users of public and public health care should be treated equally. The purpose of this study was to determine a general description of the relationship between care of the BPJS care and public services to patient satisfaction. The method used in journal collection uses Google Scholar and Mendeley 2015-2020 issues. The literature review results on the relationship between nursing care services and public services to patient satisfaction. This is based on the results of patient satisfaction where the satisfaction of patients using BPJS is lower than that of general patients. This is evident from every journal available that shows that BPJS patient satisfaction is still low. And there are differences between BPJS patients and general patients regarding the quality provided in services such as discriminatory treatment, convoluted registration process, and feeling not served according to standard procedures.
\end{abstract}

Keywords: patient satisfaction, BPJS patient, general patient. 


\section{Pendahuluan}

Kesehatan adalah keperluan masyarakat untuk mendapatkan kehidupan yang pantas dan produktif. maka perlunya badan penyelenggaraan pelayanan kesehatan yang dikendalikan oleh cost dan mutunya. Ditegaskan bahwa setiap individu memiliki hak yang sama dalam mendapatkan akses atau sumber daya di bidang kesehatan dan mendapatkan layanan kesehatan yang aman, berkualitas, dan terjangkau, sesuai dengan Undang-Undang Nomor 36 Tahun 2009. "setiap orang hendak hidup sejahtera lahir dan batin, bertempat tinggal, dan mendapatkan lingkungan hidup yang baik dan sehat serta hendak memperoleh pelayanan kesehatan" (Undang-Undang Nomor 36 pasal $28 \mathrm{H}$ ayat (1), 2009) dan "Negara bertanggung jawab atas penyediaan fasilitas pelayanan kesehatan dan fasilitas pelayanan umum yang baik" (Undang-Undang Nomor 36 pasal 34 ayat (3), 2009). (Rusman, 2018)

Tingginya cost kesehatan membuat masyarakat kesulitan dalam mendapatkan pelayanan kesehatan. Salah satu cara yang dapat dipergunakan untuk mengurangi beban dengan menggunakan asuransi. Jaminan Kesehatan Nasional (JKN) merupakan upaya yang dilakukan pemerintah untuk memberi jaminan kesehatan kepada penduduk. BPJS yang nantinya mengambil posisi beberapa lembaga jaminan yang berada di Indonesia seperti PT. Askes Indonesia menjadi BPJS Kesehatan, sesuai dengan Undang-Undang Nomor 24 tahun 2011. BPJS sangat diharapkan oleh penduduk agar mampu memberi pelayanan kesehatan pada penduduk yang lebih layak daripada tingkat pertama sampai ke pelayanan paripurna. (Pertiwi, 2017)

Masalahan yang terjadi saat ini adalah munculnya masalah dimana ternyata klien BPJS merasa ditelantarkan oleh RS tertentu. Hal tersebut menimbulkan permasalahan yaitu banyaknya penduduk yang kurang memahami tentang prosedur dan standar layanan yang hendak diterimanya saat menggunakan fasilitas BPJS. Terjadi perselisihan pendapat yang diterimanya dari pihak BPJS dengan realita yang diterima penduduk di RS. Perwakilan petugas pengelolaan BPJS menyampaikan bahwa pasien tidak akan diperlakukan tidak adil dengan klien lain, tetapi realita di lapangan masih dijumpai pasien yang merasa mendapat perbedaan perlakuan dari selenggara pelayanan kesehatan. (Kurniawan et al, 2015)

BPJS kesehatan mencatat pada tahun 2017, 79,5 persen untuk indek kepuasan dan 89,5 persen untuk indeks kepuasan fasilitas kesehatan. Bila dibandingkan dengan indeks pada tahun 2016, 78,6 persen untuk indeks kepuasan anggota dan 76,2 persen untuk indeks kepuasan fasilitas kesehatan (BPJS Kesehatan, 2017)

\section{BPJS (Badan Penyelenggara Jaminan Sosial)}

\section{Landasan Teori}

Menurut Tunggal (2016) BPJS merupakan badan hukum yang dibentuk untuk menyelenggarakan program jaminan, program jaminan ini terbagi dari beberapa program yaitu jaminan kesehatan, jaminan kecelakaan, hari tua, dan jaminan kematian. Menurut UU no 24 tahun 2011 pasal 5 ayat (2) menyebutkan fungsi dari BPJS untuk penyelenggaraan jaminan Kesehatan, kematian, kecelakaan kerja, hari tua dan jaminan pensiun. 


\section{Pelayanan Umum}

Pelayanan publik diartikan sebagai pemberi pelayanan atau melayani semua yang di perlukan oleh penduduk yang memiliki keperluan pada kelompok itu sesuai aturan pokok yang ada dan pelaksanaan yang telah ditentukan. Tujuan layanan publik untuk memuaskan masyarakat. (Kurniawan et al, 2015)

\section{Kepuasan}

Kepuasan pasien dipengaruhi oleh sikap dan pendekatan dari perawat dan tenaga medis lain kepada pasien dan keluarga pasien terhadap kualitas pelayanan keperawatan baik yang diterima oleh pasien maupun keluarga pasien. Tindakan perawat yang di maksud yaitu tindakan perawat yang berkaitan dengan enam standar keselamatan pasien (Widiasari, et al, 2019).

Kepuasan konsumen dalam menggunakan jasa layanan dipengaruhi dengan faktorfaktor sebagai berikut:

1. Responsiveness merupakan ketanggapan dalam menanggapi keluhan klien.

2. Pemahaman orang yang menggunakan jasa perihal layanan yang akan diterima, pada persoalan ini segi komunikasi sangat diperlukan untuk memudahkan dalam pemahaman jenis pelayanan.

3. Emphaty (sikap peduli) sikap yang ditunjukan oleh petugas kesehatan, komunikasi yang baik, dan memahami kebutuhan pelanggan. Sikap ini yang akan menyentuh emosi pasien, dan factor ini akan mempengaruhi tingkat kepatuhan pasien (compliance).

4. Cost besarnya cost pelayanan bisa dikatakan sebagai sumber moral pasien dan keluarganya, "yang penting sembuh" sehingga mengakibatkan mereka menerima saja jenis keperawatan dan teknologi yang ditawarkan oleh petugas kesehatan yang mengakibatkan biaya perawatan menjadi mahal.

5. Tangibility (wujud) meliputi kerapian petugas, fasilitas fisik, kondisi kebersihan, kenyamanan ruangan, perlengkapan karyawan dan sarana komunikasi.

6. Assurance merupakan keterampilan dalam sikap dan sopan santun para staf, keamanan yang ditunjukan oleh petugas.

7. Reliability (kehandalan) merupakan kemampuan dan keterampilan petugas kesehatan dalam memberikan layanan yang menjanjikan dengan cepat dan memberi kepuasan.

\section{Metode Penelitian}

Desain penelitian ini menggunakan desain penelitian literature review. Penelitian ini berdasarkan kumpulan dari jurnal yang telah ditelaah, dan disusun secara sistematis, dan dibandingkan satu sama lain serta dibahas literature review terkait. Sumber Penelusuran yang bersumber dari google scholar, mendeley terbitan tahun 2015-2020 dengan kata kunci : kepuasan pasien, pasien bpjs, pasien umum. Hasil pengumpulan jurnal pada penelitian ini mendapatkan 18 jurnal. Tentang hubungan asuhan keperawatan pelayanan BPJS dan pelayanan umum terhadap kepuasan pasien. 


\section{Hasil dan Pembahasan}

\begin{tabular}{|c|c|c|c|c|c|}
\hline No & Peneliti & Sampel & Judul & Sumber & Hasil/kesimpulan \\
\hline 1 & $\begin{array}{l}\text { Yudo } \\
\text { kurniawan, } \\
\text { agung } \\
\text { pujianto, sri } \\
\text { andayani }\end{array}$ & 65 & $\begin{array}{l}\text { Analisis } \\
\text { perbedaan } \\
\text { pelayanan } \\
\text { kesehatan } \\
\text { pasien } \\
\text { dan BPJS } \\
\text { umum pasien } \\
\text { BPJS) }\end{array}$ & $\begin{array}{l}\text { Jurnal } \\
\text { Dinamika } \\
\text { Administrasi } \\
\text { Bisnis } \\
\text { No.1, Maret } \\
2015\end{array}$ & 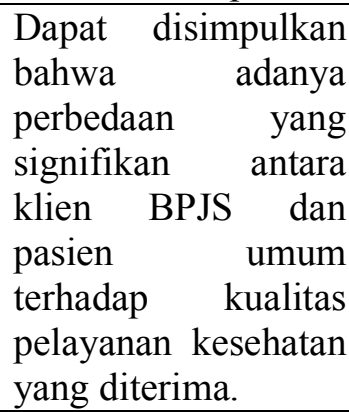 \\
\hline 2 & $\begin{array}{l}\text { Ambar Sari, } \\
\text { Primatika } \\
\text { Ichsan, } \\
\text { Burhannudin } \\
\text { Alam, Yusuf }\end{array}$ & 74 & $\begin{array}{l}\text { Perbedaan } \\
\text { tingkat } \\
\text { kepuasan } \\
\text { pasien bpjs } \\
\text { dengan pasien } \\
\text { umum di rsud } \\
\text { dr.soediran } \\
\text { mangun } \\
\text { sumarso } \\
\text { wonogiri }\end{array}$ & $\begin{array}{l}\text { Naskah Publik, } \\
\text { Universitas } \\
\text { Muhammadiya } \\
\text { h Surakarta }\end{array}$ & $\begin{array}{lr}\text { Dari } & \text { kesimpulan } \\
\text { mendapatkan } & \text { hasil } \\
\text { sebesar } & 106,14 \\
\text { tingkat } & \text { kepuasan } \\
\text { pasien } & \text { umum } \\
\text { sedangkan } & \text { sebesar } \\
\text { 66,62 pasien bpjs. }\end{array}$ \\
\hline 3 & $\begin{array}{l}\text { Sarah } \\
\text { Imelda, } \\
\text { ezzah } \\
\text { nahrisah }\end{array}$ & 71 & $\begin{array}{l}\text { Analisis tingkat } \\
\text { mutu pelayanan } \\
\text { rawat inap } \\
\text { dalam upaya } \\
\text { peningkatan } \\
\text { kepuasan } \\
\text { pasien di RSUP } \\
\text { adam malik } \\
\text { medan (studi } \\
\text { perbandingan } \\
\text { antara pasien } \\
\text { umum dan } \\
\text { pasien bpjs ) }\end{array}$ & $\begin{array}{l}\text { Jurnal Ilmiah } \\
\text { AMIK Labuhan } \\
\text { Batu } \\
\text { Vol.3 No.3, } \\
\text { September } \\
2015 \\
\text { Prodi } \\
\text { Manajemen } \\
\text { STIE Harapan } \\
\text { Medan }\end{array}$ & $\begin{array}{lr}\text { Hasil analisis } \\
\text { didapatkan sebanyak } \\
0.2 \text { pada peserta bpjs } \\
\text { sedangkan pada } \\
\text { klien non bpjs } \\
\text { sebesar } 0.001 & \text { dapat } \\
\text { disimpulkan tidak } \\
\text { terdistribusi } & \text { secara } \\
\text { normal. } & \end{array}$ \\
\hline 4 & $\begin{array}{l}\text { Musdalifah, } \\
\text { irwandy, } \\
\text { alimin } \\
\text { maidin }\end{array}$ & 100 & $\begin{array}{l}\text { Analisis } \\
\text { perbedaan } \\
\text { kepuasan } \\
\text { pasien JKN dan } \\
\text { UMUM di } \\
\text { RSUD } \\
\text { Bantaeng tahun } \\
2015\end{array}$ & $\begin{array}{l}\text { Jurnal } \\
\text { Kebijakan } \\
\text { Kesehatan } \\
\text { Indonesia } \\
\text { Vol. 5 No.1, } \\
\text { Maret 2016 } \\
\text { Hal 33-39 } \\
\text { Fakultas } \\
\text { Kesehatan } \\
\text { Masyarakat } \\
\text { Universitas } \\
\text { Hasanuddin }\end{array}$ & 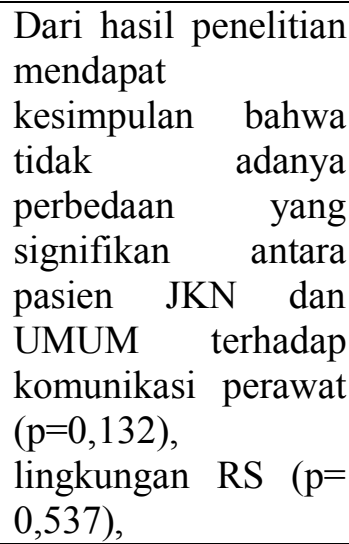 \\
\hline
\end{tabular}




\begin{tabular}{|c|c|c|c|c|c|}
\hline & & & & & $\begin{array}{l}\text { responsiveness } \\
(\mathrm{p}=0,227), \\
\text { manajemen rasa } \\
\text { sakit }(\mathrm{p}=0,479), \\
\text { komunikasi } \\
\text { kefarmasian } \\
(\mathrm{p}=0,062) \text {, discharge } \\
\text { informasi }(0,952) \text {, } \\
\text { dan komunikasi } \\
\text { dokter }(\mathrm{p}=0,676) .\end{array}$ \\
\hline 5 & $\begin{array}{l}\text { R. moh } \\
\text { naufal roby } \\
\text { firmansyah, } \\
\text { christyana } \\
\text { Sandra, eri } \\
\text { witcahyo }\end{array}$ & 94 & $\begin{array}{l}\text { Perbedaan } \\
\text { kepuasan } \\
\text { antara pasien } \\
\text { peserta jaminan } \\
\text { kesehatan } \\
\text { nasional } \\
\text { dengan umum } \\
\text { berdasarkan } \\
\text { mutu pelayanan } \\
\text { kesehatan di } \\
\text { instalasi rawat } \\
\text { inap RSD dr, } \\
\text { soebandi } \\
\text { Jember }\end{array}$ & $\begin{array}{l}\text { Artikel Ilmiah } \\
\text { Hasil Penelitian } \\
\text { Mahasiswa } \\
2016, \\
\text { Bagian } \\
\text { Administrasi } \\
\text { Dan Kebijakan } \\
\text { Kesehatan, } \\
\text { Fakultas } \\
\text { Kesehatan } \\
\text { Masyarakat } \\
\text { Universitas } \\
\text { Jember }\end{array}$ & $\begin{array}{lr}\text { Dari } & \text { analisis } \\
\text { didapatkan } & 24 \% \\
\text { pasien umum merasa } \\
\text { puas dan } & 75,36 \% \\
\text { pasien bpjs } & \text { merasa } \\
\text { kurang puas. }\end{array}$ \\
\hline 6 & $\begin{array}{l}\text { Deta } \\
\text { Sanastya } \\
\text { Riska Ts }\end{array}$ & 185 & $\begin{array}{l}\text { perbedaan } \\
\text { kualitas } \\
\text { pelayanan } \\
\text { rawat inap } \\
\text { pasien } \\
\text { pengguna BPJS } \\
\text { dan non BPJS } \\
\text { di RSUD } \\
\text { I.A.MOEIS } \\
\text { Samarinda }\end{array}$ & $\begin{array}{l}\text { eJournal } \\
\text { Administrasi } \\
\text { Negara } \\
\text { Vol.4 No. 1, } \\
2016 \\
\text { Program S1 } \\
\text { Administrasi } \\
\text { Negara, } \\
\text { Fakultas Ilmu } \\
\text { Sosial Dan } \\
\text { Ilmu Politik } \\
\text { Universitas } \\
\text { Mulawarman } \\
\text { ISSN: 2420- } \\
\text { 2430 }\end{array}$ & $\begin{array}{l}\text { Dari pengukuran } \\
\text { analisis } \\
\text { menunjukkan mutu } \\
\text { pelayanan yang } \\
\text { diberikan kepada } \\
\text { klien bpjs dan non } \\
\text { bpjs tidak terjadi } \\
\text { perbedaan. }\end{array}$ \\
\hline 7 & $\begin{array}{l}\text { Arlina dewi, } \\
\text { naufal kurnia } \\
\text { ramadhan }\end{array}$ & 200 & $\begin{array}{l}\text { The difference } \\
\text { of satisfaction } \\
\text { level in bpjs } \\
\text { health } \\
\text { insurance } \\
\text { patient and non } \\
\text { insurance } \\
\text { patient toward } \\
\text { health service }\end{array}$ & $\begin{array}{l}\text { International } \\
\text { Journal Of } \\
\text { Public Health } \\
\text { Science } \\
\text { (IJPHS) } \\
\text { Vol. } 5 \text { No. 1, } \\
\text { maret 2016, } \\
\text { Universitas } \\
\text { Muhammadiya }\end{array}$ & $\begin{array}{l}\text { Dari hasil penelitian } \\
\text { menunjukkan } \\
\text { kepuasan tertinggi } \\
\text { pada klien non } \\
\text { asuransi adalah pada } \\
\text { jaminan (-1,002) } \\
\text { terendah tangibles (- } \\
1,357) \text { dan kepuasan } \\
\text { tertinggi klien Bpjs }\end{array}$ \\
\hline
\end{tabular}




\begin{tabular}{|c|c|c|c|c|c|}
\hline & & & & $\begin{array}{l}\text { h Yogyakarta } \\
\text { pp 36-40 } \\
\text { ISSN: 2252- } \\
8806\end{array}$ & $\begin{array}{l}\text { pada assurance (- } \\
1.085) \text { terendah pada } \\
\text { daya tanggap (- } \\
1,367) \text { keduanya } \\
\text { diklasifikasikan ke } \\
\text { dalam tingkat } \\
\text { kepuasan rendah. }\end{array}$ \\
\hline 8 & $\begin{array}{l}\text { Aisah ayu } \\
\text { nur pertiwi }\end{array}$ & 60 & $\begin{array}{l}\text { Analisis } \\
\text { perbedaan } \\
\text { kualitas } \\
\text { pelayanan pada } \\
\text { pasien BPJS } \\
\text { dan pasien } \\
\text { umum terhadap } \\
\text { kepuasan } \\
\text { pasien di rawat } \\
\text { jalan RSUD } \\
\text { kota Surakarta }\end{array}$ & $\begin{array}{l}\text { Jurnal } \\
\text { Manajemen } \\
\text { Daya saing } \\
\text { Vol. 18 No. 2, } \\
\text { Desember } \\
\text { 2016. Hlm 113- } \\
\text { 121 } \\
\text { Studi Magister } \\
\text { Manajemen, } \\
\text { Universitas } \\
\text { Muhammadiya } \\
\text { h Surakarta } \\
\text { ISSN: 1411- } \\
\text { 3422 } \\
\text { DOI: } \\
\text { 10.23917/dayas } \\
\text { aing.v18i2.450 } \\
8\end{array}$ & \begin{tabular}{lr}
\multicolumn{2}{l}{ Dari hasil penelitian } \\
didapatkan & sebesar \\
20,50 & tingkat \\
kepuasan & pasien \\
umum & sedangkan \\
sebesar & 17,19 \\
pasien bpjs. &
\end{tabular} \\
\hline 9 & $\begin{array}{l}\text { Maristanna } \\
\text { millatal haq, } \\
\text { windu } \\
\text { santoso, ana } \\
\text { zakiyah }\end{array}$ & 70 & 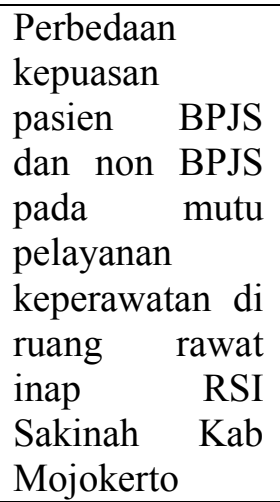 & $\begin{array}{l}\text { Program } \\
\text { Ilmu } \\
\text { Keperawatan } \\
\text { Stikes r Bina } \\
\text { Sehat PPNI } \\
\text { Mojokerto. }\end{array}$ & $\begin{array}{l}\text { Dari hasil penelitian } \\
\text { menunjukkan bahwa } \\
\text { sebagian besar } \\
\text { pasien bpjs merasa } \\
\text { puas sebanyak } 60 \% \\
\text { sedangkan pasien } \\
\text { non bpjs merasa } \\
\text { puas sebanyak } \\
94,3 \% \text {. }\end{array}$ \\
\hline 10 & $\begin{array}{l}\text { Romaji, } \\
\text { Latifatun } \\
\text { Nasuhah }\end{array}$ & 100 & $\begin{array}{l}\text { Analisis } \\
\text { kepuasan } \\
\text { pasien terhadap } \\
\text { pelayanan } \\
\text { kesehatan pada } \\
\text { peserta BPJS } \\
\text { (badan } \\
\text { penyelenggara } \\
\text { jaminan sosial) } \\
\text { dan NON BPJS } \\
\text { di RSUD } \\
\text { Gambiran }\end{array}$ & $\begin{array}{l}\text { Preventia: The } \\
\text { Indonesian } \\
\text { Journal Of } \\
\text { Public Health } \\
\text { Vol.3 No. 2, } \\
\text { Desember 2018 } \\
\text { ISSN: 2528- } \\
\text { 2999 } \\
\text { DOI: } \\
\text { 10.17977/um04 } \\
\text { 4v3i2p143-147 }\end{array}$ & $\begin{array}{l}\text { Dari hasil penelitian } \\
\text { sebesar } 80 \% \\
\text { pengguna BPJS dan } \\
88 \% \text { pasien umum } \\
\text { merasa puas dengan } \\
\text { pelayanan. }\end{array}$ \\
\hline
\end{tabular}




\begin{tabular}{|c|c|c|c|c|c|}
\hline & & & $\begin{array}{l}\text { Kediri Jawa } \\
\text { Timur }\end{array}$ & & \\
\hline 11 & Lilik darwati & 70 & $\begin{array}{l}\text { Analisis } \\
\text { perbandingan } \\
\text { kepuasan } \\
\text { pasien terhadap } \\
\text { pelayanan } \\
\text { kebidanan pada } \\
\text { peserta bpjs } \\
\text { (badan } \\
\text { penyelenggara } \\
\text { jaminan sosial) } \\
\text { dan non bpjs di } \\
\text { ruang bersalin } \\
\text { rsud soegiri } \\
\text { lamongan jawa } \\
\text { timur }\end{array}$ & $\begin{array}{l}\text { Journal for } \\
\text { Quality in } \\
\text { Women's } \\
\text { Health } \\
\text { Vol.1 No.2 } \\
\text { September } \\
2018 \\
\text { pp. } 28 \text { - 34 } \\
\text { Universitas } \\
\text { Islam } \\
\text { Lamongan } \\
\text { p-ISSN: 2615- } \\
6660 \\
\text { e-ISSN: 2615- } \\
\text { 6644 } \\
\text { DOI: } \\
\text { 10.30994/jqwh. } \\
\text { v1i2.14 }\end{array}$ & $\begin{array}{lr}\text { Dari hasil } & \text { analisis } \\
\text { didapatkan } & \text { hampir } \\
\text { seluruh responden } & \\
\text { non bpjs } & 94,9 \% \\
\text { merasa puas dan } & \\
\text { responden } & \text { dengan } \\
\text { bpjs 77,4\% } & \text { merasa } \\
\text { puas } & \text { dengan } \\
\text { pelayanan } & \text { yang } \\
\text { diberikan di ruang } \\
\text { nifas. }\end{array}$ \\
\hline 12 & $\begin{array}{l}\text { Dian Novita } \\
\text { ria }\end{array}$ & 100 & $\begin{array}{l}\text { Analisis } \\
\text { komparatif } \\
\text { kualitas } \\
\text { pelayanan } \\
\text { pasien BPJS } \\
\text { dan pasien } \\
\text { UMUM } \\
\text { terhadap } \\
\text { kepuasan } \\
\text { pasien } \\
\text { puskesmas } \\
\text { (studi empiris } \\
\text { pada } \\
\text { puskesmas } \\
\text { balarejo } \\
\text { kab.madiun) }\end{array}$ & $\begin{array}{l}\text { Fakultas } \\
\text { Ekonomi Dan } \\
\text { Bisnis, } \\
\text { Universitas } \\
\text { PGRI Madiun }\end{array}$ & $\begin{array}{l}\text { Dari hasil nilai mean } \\
84.75 \text { pasien bpjs } \\
\text { dan } 86.40 \text { pasien } \\
\text { umum merasa puas. }\end{array}$ \\
\hline 13 & $\begin{array}{l}\text { Yosi arum } \\
\text { ariningtyas, } \\
\text { purnomo } \\
\text { suryantoro, } \\
\text { mufdlilah }\end{array}$ & 70 & $\begin{array}{l}\text { Perbandingan } \\
\text { kepuasan } \\
\text { pasien terhadap } \\
\text { pelayanan } \\
\text { kebidanan pada } \\
\text { peserta BPJS } \\
\text { dan NON BPJS }\end{array}$ & $\begin{array}{l}\text { Jurnal Medika: } \\
\text { Karya Ilmiah } \\
\text { Kesehatan } \\
\text { Vol. 4 No. 1 } \\
\text { tahun 2019 } \\
\text { Studi Magister } \\
\text { Kebidanan } \\
\text { Universitas } \\
\text { 'AISYIYAH } \\
\text { ISSN: 2541- } \\
\text { 4615 } \\
\text { DOI: }\end{array}$ & $\begin{array}{lr}\text { Hasil } & \text { analisis } \\
\text { didapatkan } & \text { hasil } \\
\text { sebesar } & 94,9 \% \\
\text { pasien non } & \text { bpjs } \\
\text { merasa puas } & \text { dan } \\
\text { responden } & \text { dengan } \\
\text { bpjs 77,4\% } & \text { merasa } \\
\text { puas } & \text { dengan } \\
\text { pelayanan kebidanan } \\
\text { di ruang postpartum. }\end{array}$ \\
\hline
\end{tabular}




\begin{tabular}{|c|c|c|c|c|c|}
\hline & & & & $\begin{array}{l}\text { 10.35728/jmkik } \\
. v 4 i 1.91\end{array}$ & \\
\hline 14 & $\begin{array}{l}\text { Odi supandri, } \\
\text { otniel } \\
\text { ketaren, lia } \\
\text { rosa veronika }\end{array}$ & 158 & $\begin{array}{l}\text { Perbedaan } \\
\text { kualitas } \\
\text { pelayanan pada } \\
\text { pasien bpjs dan } \\
\text { pasien umum } \\
\text { rawat inap di } \\
\text { rumah sakit } \\
\text { muhammadiya } \\
\text { h medan tahun } \\
2019\end{array}$ & $\begin{array}{l}\text { Jurnal Ilmiah } \\
\text { Simantek Vol.3 } \\
\text { No.3 Agustus } \\
2019 \\
\text { Universitas Sari } \\
\text { Mutiara } \\
\text { ISSN: } \\
0414\end{array}$ & $\begin{array}{l}\text { Hasil analisis } 87,5 \% \\
\text { pasien umum merasa } \\
\text { puas dan } 67,3 \text { klien } \\
\text { Bpjs merasa kurang } \\
\text { puas pada pelayanan } \\
\text { yang diterima. }\end{array}$ \\
\hline 15 & $\begin{array}{l}\text { Trisna } \\
\text { awalinda, } \\
\text { julianus ake, } \\
\text { m. } \\
\text { consolatrix } \\
\text { da silva }\end{array}$ & 37 & $\begin{array}{l}\text { Tingkat } \\
\text { kepuasan } \\
\text { pasien peserta } \\
\text { BPJS kesehatan } \\
\text { terhadap } \\
\text { kualitas } \\
\text { pelayanan di } \\
\text { puskesmas } \\
\text { bailing kota } \\
\text { manado }\end{array}$ & $\begin{array}{l}\text { JUIPERDO } \\
\text { Vol.7 No.1 } \\
\text { tahun } 2019 \\
\text { Fakultas } \\
\text { Keperawatan } \\
\text { Universitas } \\
\text { Katolik De La } \\
\text { Salle Manado }\end{array}$ & $\begin{array}{lr}\text { Hasil penelitian } \\
\text { didapatkan } & 73 \% \\
\text { yang mengatakan } \\
\text { puas } & \text { dengan } \\
\text { pelayanan } & \text { yang } \\
\text { diterima. } & \end{array}$ \\
\hline 16 & $\begin{array}{l}\text { Kus daru } \\
\text { widayati, } \\
\text { Kartika } \\
\text { yuliantari }\end{array}$ & 50 & $\begin{array}{l}\text { Kualitas } \\
\text { pelayanan } \\
\text { terhadap } \\
\text { kepuasan } \\
\text { pasien } \\
\text { pengguna bpjs } \\
\text { pada RSUD } \\
\text { XYZ }\end{array}$ & $\begin{array}{l}\text { Jurnal AKRAB } \\
\text { Juara } \\
\text { Vol.5 No.1 } \\
\text { February 2020. } \\
\text { Hlm 220-227 } \\
\text { Fakultas } \\
\text { Ekonomi dan } \\
\text { Bisnis } \\
\text { Universitas } \\
\text { Bina Sarana } \\
\text { Informatika } \\
\end{array}$ & $\begin{array}{lr}\text { Hasil penelitian } \\
\text { menunjukkan bahwa } \\
\text { kualitas pelayanan } \\
\text { berpengaruh positif } \\
\text { dan signifikan } \\
\text { terhadap kepuasan } \\
\text { pasien sebesar } & 78 \% \\
\text { sedangkan } & 22 \% \\
\text { dipengaruhi } & \text { oleh } \\
\text { faktor lain. } & \end{array}$ \\
\hline 17 & $\begin{array}{l}\text { Mulyati, Eri } \\
\text { Susanti, } \\
\text { Septiyani } \\
\text { Aryati, Elly } \\
\text { Mardhotillah, } \\
\text { Maftukhah, } \\
\text { Gati } \\
\text { Sulistyowati, } \\
\text { Novi } \\
\text { Indrayati, } \\
\text { Livana PH }\end{array}$ & 105 & $\begin{array}{l}\text { Tingkat } \\
\text { Kepuasan } \\
\text { Pasien Dalam } \\
\text { Menerima } \\
\text { Pelayanan } \\
\text { Asuhan } \\
\text { Keperawatan }\end{array}$ & $\begin{array}{lr}\text { Jurnal } \\
\text { Keperawatan } \\
\text { Vol.12 No.1 } \\
\text { Mater 2020. } \\
\text { Rumah } & \text { Sakit } \\
\text { Islam } & \text { Kendal } \\
\text { Dan } & \text { Studi } \\
\text { NERS } & \text { Stikes } \\
\text { Kendal } & \\
\text { p-ISSN: } & 2085- \\
\text { 1049 } & \\
\text { e-ISSN: } & 2549- \\
8118 & \\
\end{array}$ & $\begin{array}{l}\text { Dari hasil penelitian } \\
\text { didapatkan sebanyak } \\
76,2 \% \text { dan terdapat } \\
23,8 \% \text { responden } \\
\text { merasa puas dengan } \\
\text { pelayanan } \\
\text { keperawatan di RSI. }\end{array}$ \\
\hline 18 & $\begin{array}{l}\text { Ariany dhesi } \\
\text { puspitasari, }\end{array}$ & 60 & $\begin{array}{l}\text { Perbedaan } \\
\text { tingkat }\end{array}$ & $\begin{array}{l}\text { Dunia } \\
\text { keperawatan: }\end{array}$ & $\begin{array}{l}\text { Dari hasil hasil } \\
\text { analisis didapatkan } p\end{array}$ \\
\hline
\end{tabular}




\begin{tabular}{|c|c|c|c|}
\hline $\begin{array}{l}\text { ending } \\
\text { pertiwiwati, } \\
\text { ichsan rizany }\end{array}$ & $\begin{array}{l}\text { kepuasan } \\
\text { pasien umum } \\
\text { dengan pasien } \\
\text { BPJS } \\
\text { berdasarkan } \\
\text { mutu pelayanan } \\
\text { keperawatan }\end{array}$ & $\begin{array}{l}\text { Jurnal } \\
\text { Keperawatan } \\
\text { Dan Kesehatan } \\
\text { Vol. 8 No. 1 } \\
\text { Maret 2020. } \\
\text { Hlm 93-100 } \\
\text { Studi Ilmu } \\
\text { Keperawatan, } \\
\text { Universitas } \\
\text { Lambung } \\
\text { Mangkurat } \\
\text { e-ISSN: 2541- } \\
\text { 5980 } \\
\text { p-ISSN: 2337- } \\
\text { 8212 } \\
\text { DOI: } \\
\text { 10.20527/dk.v8 } \\
\text { i1.5869 }\end{array}$ & $\begin{array}{lr}\text { value } & >a \\
(0,50>0,05), & \text { dapat } \\
\text { diartikan } & \text { antara } \\
\text { kepuasan } & \text { klien } \\
\text { umum dan klien bpjs } & \text { tidak } \\
\text { perbedaan } & \text { terdapat } \\
\text { signifikan } & \\
\text { berdasarkan } & \text { kualitas } \\
\text { pelayanan } & \\
\text { keperawatan. }\end{array}$ \\
\hline
\end{tabular}

Dari hasil 18 jurnal yang didapatkan tentang kepuasan pasien BPJS dan Umum terhadap asuhan keperawatan, berdasarkan artikel yang telah dikumpulkan diperoleh hasil kajian mengenai kepuasan pasien BPJS dan Umum dalam menerima pelayanan kesehatan selama pasien berada di rumah sakit atau puskesmas. Kepuasan pasien dapat dinilai dari beberapa faktor di beberapa jurnal memiliki keterkaitan yang rata-rata sama dalam penilai kepuasan terhadap pasien.

\section{Hubungan Pelayanan Bpjs Dan Pelayanan Umum Terhadap Kepuasan Pasien}

Penelitian yang dilakukan di dalam indonesia menunjukkan adanya Perbedaan asuhan keperawatan yang diberikan kepada pasien BPJS sehingga berhubungan dengan kepuasan pasien. Sebagian besar pasien pengguna BPJS Kesehatan merasa kurang puas terhadap pelayanan yang diberikan. Seperti menurut penelitian Kurniawan, Pujianto, Andayani (2015) munculnya permasalahan ternyata klien Bpjs merasa ditelantarkan oleh RS tertentu. Hal tersebut menimbulkan permasalah bahwa masih banyak penduduk yang tidak paham tentang prosedur dan standar layanan yang hendak diterimanya saat menggunakan fasilitas BPJS. Terjadinya perbedaan pendapat antara pihak BPJS yang mengatakan klien tidak akan mendapatkan perlakuan yang tidak adil dengan klien lain, tapi realitanya di lapangan masih ada pasien yang merasakan mendapat perlakuan berbeda.

Menurut penelitian yang dilakukan oleh primatika ambar sari (2015) derajat kepuasan klien Bpjs masih kurang bila dibandingkan dengan klien umum hal itu dikarenakan pelayanan rumah sakit yang masih kurang dalam menangani diagnosis dan terlalu lama menunggu membuat pasien merasa tidak puas bukan hanya itu saja tetapi petugas rumah sakit tidak transparan terhadap jenis obat dan jumlah yg sudah digunakan. Maka dari itu diperlukan perbaikan yang maksimal untuk meningkatkan kepuasan pasien sehingga menciptakan cermin yang baik untuk rumah sakit tersebut. Menurut penelitian Sarah Imelda menunjukkan adanya perbedaan dan pengaruh signifikan terhadap 
kepuasan dengan mutu pelayanan hal ini dapat memberi contoh untuk RSU supaya lebih memperhatikan pelayanan yang diberi untuk meningkatkan kepuasan pasien. Meskipun klien umum percaya dengan layanan yang diberikan oleh perawat yang handal dan terbaik untuk pasien namun masih ada yang perlu diperhatikan dan diperbaiki untuk meningkatkan kepuasan pasien yang lebih maksimal.

Dari penelitian yang dilakukan Musdalifah, Irwandy, Maidin (2016) menilai kepuasan pasien dari komunikasi perawat dan dokter, lingkungan RS, responsiveness, manajemen rasa sakit, komunikasi obat, discharge informasi. Sanitasi lingkungan RS umumnya baik hanya ketenangan area rawat inap yang buruk karena ruangan perawatan kelas III tidak ada penyekat atau tirai pemisah sehingga menimbulkan rasa tidak nyaman karena pengunjung ataupun keluarga klien lainnya. Permasalahan dalam memberikan pelayanan kesehatan pada pasien BPJS karena komplain dari pasien BPJS kepada ketanggapan petugas yang membuat pasien menunggu terlalu lama untuk mendapatkan pelayanan ( Riska, 2016).

Menurut penelitian Pertiwi (2017) kepuasan pasien BPJS lebih rendah disebabkan oleh adanya pelayanan yang tidak efisien dan efektif, penyebabnya ialah rujukan yang ditunjuk oleh bpjs terbatas dan tidak fleksibel karena pasien bpjs diperbolehkan memilih satu faskes dan tidak bisa ke faskes lain walaupun bekerjasama dengan BPJS. Pasien bpjs juga tidak puas terhadap aspek assurance dan tangibles karena suasana yang diberikan rumah sakit kurang nyaman, tidak sesuai harapan dan fasilitas yang kurang memenuhi (Haq, 2018). Kepuasan pasien bpjs yang masih rendah terhadap kualitas pelayanan rumah sakit dapat dilihat dari aspek kehandalan yang masih kurang, daya tanggap yang kurang, tidak adanya jaminan, tidak adanya sikap empati, aspek bukti yang tidak baik. Hal tersebut karena pelayanan yang tidak efektif dan efisien. Berdasarkan fakta di lapangan masalah ketidakpuasan terjadi pada keterlambatan pelayanan, lamanya proses masuk keruang perawatan, sistem yang berbelit-belit membuat pasien tidak merasa puas atas pelayanan yang ada (Supandri, Ketaren, 2019).

Menurut penelitian Romaji \& Nasihah (2018) menunjukkan hampir semua pasien bpjs dan umum merasa puas dengan pelayanan kesehatan hal ini dapat dilihat dari beberapa dimensi sudah sesuai dengan yang diharapkan pasien seperti ruang perawatan yang bersih, rapi, bagus, keamanan dan kenyaman yang diberikan, sikap petugas yang baik. Pasien bpjs merasa puas pada pelayanan karena harapan yang dimiliki pasien sesuai dengan keinginan, keluhan yang disampaikan ke pengelola bpjs yang menjadi perhatian pihak pemberi pelayanan kesehatan, pasien umum memiliki kepuasan lebih tinggi dikarenakan klien umum dapat biayai sendiri atas pelayanan yang dirasakan maka biasanya klien umum bebas memilih ruangan yang lebih nyaman sehingga mereka cenderung menuntut pelayanan terbaik (Darwati, 2018). Tidak ada perbedaan antara pasien umum dan bpjs yang terlihat dari tagihan yang terperinci dan jelas, kemudahan mengurus administrasi, penjelasan yang baik dan jelas tentang tindakan, keterampilan memberi perawatan, bersikap baik dan sopan sesuai etika, kepedulian terhadap pasien memberikan perhatian dan perawatan dengan baik, bagaimana menangani keluhan pasien yang memiliki hasil kepuasan tidak jauh berbeda (Ariningtyas, 2019). Sudah ada peningkatan kualitas pelayanan karena didukung dengan kenaikan iuran bpjs yang diterapkan oleh pemerintah dengan demikian pasien bpjs mengharapkan mendapatkan pelayanan secara adil dan bermutu (Widayati \& Yuliantari, 2020) 


\section{Kesimpulan}

Dari 18 Jurnal penelitian yang dilakukan oleh peneliti sebelumnya didapatkan bahwa pelayanan bpjs ternyata memiliki berbagai perbedaan dalam pelayanan sehingga mempengaruhi tingkat kepuasan klien terhadap pelayanan yang diberikan. Dari 14 Jurnal menyatakan pasien bpjs merasa kurang puas dengan pelayanan kesehatan, 4 Jurnal mengatakan puas dengan pelayanan kesehatan. Dari 18 jurnal penelitian yang dilakukan oleh penelitian sebelumnya didapatkan bahwa pelayanan non bpjs atau umum memiliki tingkat kepuasan yang besar bila dibandingkan dengan pelayanan bpjs. Serta terdapat perbedaan perlakuan antara pasien bpjs dan umum, pasien bpjs lebih sering mengalami perbedaan perlakuan entah itu tentang pelayanan, ruangan, ataupun prosesnya oleh karena itu pelayanan kesehatan yang diberikan sangat mempengaruhi tingkat kepuasan yang dialami pasien.

Menurut hasil dari literature review di atas menunjukkan adanya Perbedaan asuhan keperawatan yang diberikan kepada pasien Umum sehingga dapat berhubungan dengan kepuasan pasien. Hal ini ditunjukkan berdasarkan hasil kepuasan pasien dimana kepuasan pasien pengguna BPJS lebih rendah dari pasien Umum. Hal ini terbukti dari setiap jurnal yang ada diatas menunjukkan kepuasan pasien BPJS yang masih rendah. Dan terdapat perbedaan antara pasien bpjs dan pasien umum terhadap kualitas yang diberikan dalam pelayanan seperti perlakuan yang dibeda-bedakan, proses pendaftaran yang berbelit-belit, dan merasa tidak dilayani sesuai standar prosedur. Pelayanan yang diberikan dengan baik akan menimbulkan rasa puas, bisa membuat pasien kembali berkunjung ke pelayanan kesehatan tersebut, dan bisa mempengaruhi konsumen yang lain untuk menggunakan layanan kesehatan tersebut.

\section{Daftar Pustaka}

Ambar Sari, P., Ichsan, B., \& Alam, Y. (2015). Perbedaan Tingkat Kepuasan Pasien BPJS dengan Pasien Umum di RSUD Dr. Soediran Mangun Sumarso Wonogiri. Naskah Publikasi, 1-10. Retrieved from http://eprints.ums.ac.id/40493/

Ariningtyas, Y. A. (2019). Perbandingan Kepuasan Pasien Terhadap Pelayanan Kebidanan Pada Peserta Bpjs Dan Non Bpjs. Jurnal Medika: Karya Ilmiah Kesehatan, 4(1).

Awalinda, T., Ake, J., \& Silva, M. C. da. (2019). Level of Satisfaction of Patients of Bpjs Health on Quality of Service in Puskesmas Bailang, Manado City. Jurnal Ilmiah $\quad \ldots, 7(1)$ Retrieved fromhttps://ejurnal.poltekkesmanado.ac.id/index.php/juiperdo/article/view/794

Darwati, L. (2018). Analisis Perbandingan Kepuasan Pasien terhadap Pelayanan Kebidanan pada Peserta BPJS (Badan Penyelenggara Jaminan Sosial) dan non BPJS di Ruang Bersalin RSUD Soegiri Lamongan Jawa Timur. Journal for Quality in Women's Health, 1(2), 28-34. https://doi.org/10.30994/jqwh.v1i2.14

Dewi, A., \& Ramadhan, N. K. (2016). The Difference of Satisfaction Level in BPJS Health Insurance Patient and Non Insurance Patient toward Health Service. International Journal of Public Health Science (IJPHS), 5(1), 36. https://doi.org/10.11591/ijphs.v5i1.4760

Haq, M. M. (2018). Perbedaan kepuasan pasien bpjs dan non bpjs pada mutu pelayanan keperawatan di ruang rawat inap rsi sakinah kab mojokerto. Perbedaan Kepuasan Pasien BPJS Dan Non BPJS Pada Mutu Pelayanan Keperawatan Di Ruang Rawat Inap RSI Sakinah Mojokerto. 
Imelda, S., \& Nahrisah, E. (2019). ANALISIS TINGKAT MUTU PELAYANAN RAWAT INAP DALAM UPAYA PENINGKATAN KEPUASAN PASIEN DI RSUP ADAM MALIK MEDAN (STUDI PERBANDINGAN ANTARA PASIEN UMUM DAN PASIEN BPJS). JURNAL INFORMATIKA. https://doi.org/10.36987/informatika.v3i3.221

Kurniawan, Y., Pujianto, A., \& Andayani, S. (2015). Analisis Perbedaan Pelayanan Kesehatan. Jurnal Dinamika Administrasi, (1).

Martapura, R. Z., Jica, N. K.-, Ratu, R., \& Martapura, Z. (2020). Perbedaan Tingkat Kepuasan Pasien Umum dengan Pasien BPJS berdasarkan Mutu Pelayanan Keperawatan Ariany Dhesi Puspitasari, Endang Pertiwiwati, Ichsan Rizany Program Studi Ilmu Keperawatan, Fakultas Kedokteran, Universitas Lambung Mangkurat Email Kores. 8(1), 93-100. https://doi.org/10.20527/dk.v8i1.5869

Musdalifah, M., Irwandy, I., \& Maidin, A. (2016). Analisis Perbedaan Kepuasan Pasien JKN dan Umum di RSUD Bantaeng Tahun 2015. Jurnal Kebijakan Kesehatan Indonesia : JKKI.

Mulyati, \& susanti, eri. (2020). Level of Patient Satisfaction in Receiving Service Nursing Care. 12(1), 57-62.

Naufal Roby Firmansyah, Christyana Sandra, \& Eri Witcahyo. (2016). Perbedaan Kepuasaan antara Pasien Peserta Jaminan Kesehatan Nasional dengan Umum Berdasarkan Mutu Pelayanan Kesehatan di Instalasi Rawat Inap RSD dr. Soebandi Jember. Artikel Ilmiah Hasil Penelitian Mahsiswa. Retrieved from https://repository.unej.ac.id/bitstream/handle/123456789/78414/R.Moh.Naufal Roby Firmansyah.pdf? sequence $=1$

Pertiwi, A. (2017). Analisis Perbedaan Kualitas Pelayanan Pada Pasien Bpjs Dan Pasien Umum Terhadap Kepuasan Pasien Di Rawat Jalan Rsud Kota Surakarta. Jurnal Manajemen Dayasaing, $18(2), \quad 113$. https://doi.org/10.23917/dayasaing.v18i2.4508

Profil Kesehatan Kab/Kota. (2017). https://dinkes.bantenprov.go.id/id/archive/profilkesehatan-provinsi-bant/1.html

Ria Dian Novita. (2019). Analisis komparatif kualitas pelayanan pasien BPJS dan pasien UMUM terhadap kepuasan pasien di puskesmas (studi empiris pada puskesmas balarejo kab.madiun). http://prosiding.unipma.ac.id/index.php/SIMBA/article/view/1231

Riska, D. S. (2016). Perbedaan Kualitas Pelayanan Rawat Inap Pasien Pengguna BPJS dan Non BPJS di RSUD I.A.MOEIS Samarinda. EJournal Administrasi Negara.

Romaji, R., \& Nasihah, L. (2018). ANALISIS KEPUASAN PASIEN TERHADAP PELAYANAN KESEHATAN PADA PESERTA BPJS (BADAN PENYELENGGARA JAMINAN SOSIAL) DAN NON BPJS DI RSUD GAMBIRAN KEDIRI JAWA TIMUR. Preventia: The Indonesian Journal of Public Health. https://doi.org/10.17977/um044v3i2p143-147

Rusman, A. D. P. (2018). The Relationship Between The Quality Of Health Sevices And Patien Satisfaction Of Users Of The Social Security Organizing Body (Bpjs) At The Maiwa Health Center In Enrekang Regency Nurheda 1) Usman. 1(1), 26143151. Retrieved from http://jurnal.umpar.ac.id/index.php/makes

Supandri, O. D. I., Ketaren, O., \& ... (2019). Perbedaan Kualitas Pelayanan Pada Pasien Bpjs Dan Pasien Umum Rawat Inap Di Rumah Sakit Muhammadiyah Medan Tahun 2019. JURNAL ILMIAH .... https://www.mendeley.com/researchpapers/cc18ee22-13d2-38d2-984a-5e006f157d89/ 
Tunggal, Hadi Setia. (2016). Kumpulan Peraturan Sistem Jaminan Nasional (SISN) dan Badan Penyelenggara Jaminan Social (BPJS). Jakarta: Harvarindo.

Widayati, Kus Daru; Yuliantari, Kartika. (2020). Kualitas Pelayanan Terhadap Kepuasan Pasien Pengguna BPJS Pada RSUD XYZ. Jurnal Akrab Juara, [S.1.], v. 5, n. 1, p. 220-227, feb. 2020. ISSN 2620-9861. Available at: http://akrabjuara.com/index.php/akrabjuara/article/view/957 